\title{
Demographic Analysis of Inter-Provincial Migration in Turkey and its Impact on the Development Corridors
}

\author{
By Zeynep Ozdemir* \\ Vedia Dokmeci $i^{\dagger}$
}

The present study investigates age-specific provincial migration in Turkey using both, five-year and life time measures for 2007-2008 and 2010-2011, a method which allows changes in the pattern of job markets and human settlements to be tracked. The aim of this study is first, to investigate in detail the relationship between the in-and out-migration of the provinces at the country level. The second is to determine the relationship between the in-migration and out-migration and the age-pyramids of the provinces. The third is to show the relationships between the economic development islands and the age-pyramids of the provinces. According to the results; at the provincial level, while the in-migration decreases as the distance increases between the origin provinces for the Western provinces, out-migration increases as the distance increases between the origin provinces in the East, South-East and the Black Sea regions. Although in general, distance negatively effects in-migration at the country level, for the less developed provinces in the East, South-East and the Black Sea regions, out-migration increases to the large metropolitan areas in the West. Consequently, it is therefore necessary to stimulate a public and private investment to create new jobs and to improve the quality of educational facilities.

Keywords: Age profiles, Demography, inter-provincial, Migration, Turkey.

\section{Introduction}

During the second half of the last century, Turkey experienced an intense inter-provincial migration process as a result of the transformation of its economy from agricultural to industrial and later from industrial to post-economies which resulted in its deep social, demographic, political and structural transformation. Although there have been several studies which investigated the trends and the causes on inter-regional or inter-provincial migration (Gedik 1997, Tanfer 1983, Evcil et al. 2006, Tekeli 2008, Yazgi et al. 2014), only a few took the life-cycles of migrants into consideration (Var et al. 2014) and none on the impact of migration on the population age pyramids of the origin provinces. The present study investigates the impact of in- and out-migration on the age pyramids of provinces in relation to distance between the origin and destination of migration, age profiles of migration and thus economic clusters and corridors.

\footnotetext{
${ }^{*}$ Research Assistant \& PhD Candidate, Istanbul Technical University, Turkey.

${ }^{\dagger}$ Professor, Istanbul Technical University, Turkey.
} 
There are several studies which illustrated that wide income gaps and unemployment stimulated population movement in developing countries (Skeldon 1990, Liang et al. 2002) as well as developed ones (Kontully and Shon 1994, Gordon and Lamont 1998). The impact of distance over all the population movements has already been recognized by several authors. For instance, Lee (1966) emphasized the negative impact of distance on the number of migrants, and Siegel and Woodyard (1974) demonstrated that a city's position in the urban hierarchy will affect the determinants of that city's in-migration by using data from Canada.

According to previous studies, life-cycle is another important variable to affect in-and out-migration from the provinces. A typical life-cycle contains steps - such as completion of schooling, start of a career, marriage and divorce, the birth and raising children, unemployment and retirementwhich can effect an individual or a family decision to migrate (Clark and Onaka 1983, Detang-Dessendre et al. 2008). Thus, decisions to migrate can change according to the ages and locations of migrants. Several fundamental changes in migration and redistribution within a population have been observed in relation to age-cohort characteristics and their impact on the origin provinces. According to Tobler (1995), the concept of age and space form the basics of migration laws. There have been several studies in developed countries which used age-cohort techniques to better understand spatial population movements with respect to education and working or retirement age groups (Plane 1993). According to their results, young adults and middle aged migrants are attracted to job locations, whereas older migrants are attracted to milder climates, environmental amenities, lower costs of living, quality of life and proximity to family members and friends (Liaw 1990, Walters 1994, Dokmeci and Berkoz 2000, Walters 2002). Thus, it is to be expected that younger migrants prefer to go to metropolitan areas for the higher wages and employment chances, while older ones may choose small towns (Clark and Hunter 1992) as it is already illustrated by Baccaini (2007) in Paris.

Although there is a large emphasis on the relationships both the size of migration flows and the perceived development benefits and challenges which they create (Skeldon 1990, Samers, 2009, Willis 2010), their impact on the origin regions is usually neglected.

Moreover, continuous out-migration causes the narrowing of age pyramids in the less developed regions or provinces which are located between the development clusters. The provinces with narrow age pyramids are not attractive for the investors due to the lack of young people as workers. So, migration, lack of investment and less development become a vicious cycle for these provinces. Thus, the present paper investigates the relationships between the location, age profiles and age pyramids and migration with respect to development corridors interrupted by the less developed provinces which lost population due to heavy out-migration. 


\section{Regional Socio-economic Characteristics and the Dynamics of Urban Systems}

The economic, social and politic transformation of Turkey due to technologic changes and migration had a strong impact on the demographic and urban structure in Turkey during the last half century. Turkey consists of seven regions with great disparities among them (Celebioglu and Dall'erba (2010) which caused high volume of human mobility and also transformation urban structures in a rapid rate. The Marmara Region, which includes Istanbul, is the most developed region according to production capacity, trade, population and urbanization. With respect to the socioeconomic characteristics of the regions, the Marmara Region was more industrialized $(30.9 \%)$ and had more services $(28.2 \%)$ than the other regions in 2003. Its urbanization rate was also the highest $(79 \%)$ in 2000 . The Aegean Region was the second most industrialized region (17.2\%) and the fourth with respect to services $(21.0 \%)$ in 2003 , while its urbanization ratio was the fourth $(61.4 \%)$ in 2000. In 2003, in the Central Anatolia Region, industrial employment was the fourth largest (15.3\%), its service employment was the third largest $(25.1 \%)$ and its urbanization ratio was the second largest (69.2\%) in 2000. The Mediterranean Region was the fifth highest $(12.1 \%)$ with respect to industrial employment, had the second largest service employment ratio $(27.6 \%)$ and its urbanization ratio was the fifth largest (59.7\%) in 2000. A large amount of investment in tourism played an important role for the development of the service sector in this region. The South-East Anatolian Region was the third largest with respect to industrial employment $(16.9 \%)$ and urbanization ratio $(62 \%)$, the fifth largest service employment (17.6\%). The East Anatolia and the Black Sea Regions were much less developed and had lower urbanization ratios (53\% and $49 \%$, respectively) than the other regions due to lack of necessary industrial investment and thus the large amount of out-migration from these regions to the more developed ones (Yazgi et al. 2014).

Table 1. The Ratio of Industrial, Service and Agricultural Employment Distribution According to Regions in Turkey (1990-2003)

\begin{tabular}{|c|c|c|c|c|c|c|c|c|}
\hline \multirow[b]{2}{*}{ Regions } & \multicolumn{2}{|c|}{ Agriculture (\%) } & \multicolumn{2}{|c|}{ Industry $(\%)$} & \multicolumn{2}{|c|}{ Services (\%) } & \multicolumn{2}{|c|}{ Others $(\%)$} \\
\hline & 1990 & 2003 & 1990 & 2003 & 1990 & 2003 & 1990 & 2003 \\
\hline Marmara & 18.9 & 14.2 & 33.6 & 30.9 & 17.4 & 28.2 & 20.1 & 26.7 \\
\hline Mediterranean & 57.3 & 33.8 & 9.6 & 12.1 & 10 & 17.6 & 23.2 & 26.6 \\
\hline Aegean & 54.1 & 37.9 & 12.5 & 17.2 & 10.2 & 21 & 23.2 & 23.8 \\
\hline Central A. & 50.5 & 21.3 & 10.2 & 15.3 & 10.6 & 25.1 & 28.7 & 38.3 \\
\hline South-East A. & 67.3 & 43.7 & 5.9 & 16.9 & 6.4 & 17.6 & 20.4 & 21.8 \\
\hline East A. & 71.9 & 53.2 & 3.5 & 3.8 & 4.3 & 16.9 & 20.3 & 26 \\
\hline Black Sea & 71.1 & 61.1 & 6.2 & 7.3 & 5.5 & 13.8 & 17.2 & 17.8 \\
\hline Country & 53.7 & 33.9 & 11.9 & 17.3 & 10.2 & 22.7 & 24.2 & 26.1 \\
\hline
\end{tabular}

Source: TUIK 1990, TUIK 2003. 
Table 2. Regional Urbanization Ratios in 1990 and 2003

\begin{tabular}{|l|c|c|}
\hline \multicolumn{1}{|c|}{ Regions } & $\mathbf{1 9 9 0}$ & $\mathbf{2 0 0 0}$ \\
\hline Marmara & 77.8 & 79 \\
\hline Aegean & 57.2 & 61.4 \\
\hline Mediterranean & 57.6 & 59.7 \\
\hline C.Anatolia & 64.6 & 69.2 \\
\hline Black Sea & 41.2 & 49 \\
\hline East Anatolia & 42.7 & 53 \\
\hline South-East Anatolia & 53.3 & 62 \\
\hline
\end{tabular}

Source: TUIK 1990; TUIK 2003.

As an example of an income gap within the country, the highest income per capita $(\$ 6,165)$ is in Kocaeli which is near Istanbul, and the lowest (\$568) is in Ağr1 which is located at the eastern boundary of the country. Since the 1960s, various governments have planned to spread equal levels of development throughout the country. However they have all failed to accomplish this goal (Gezici and Hewings 2007, Tekeli 2008, Celebioglu and Dall'erba 2010).

The high amount of human mobility tremendously affected urbanization and the distribution of city size groups at the country level. For instance, in 1945, there were 3 cities between 100,000-500,000, 6 cities between 50,000-100,000 and 91 cities between 10,000-50,000 together with Istanbul at the top with 860,558 people (See Table 3). In 1975, the number of cities between 100,000-500,000 increased to 26, the number of cities between 50,000-100,000 to 29 and the number of cities between 10,00050,000 to 269 and the population of Istanbul to 3,904,588 people (See Table 3 ). During this period, increase in the urbanization ratio is almost equal to the increase in the urbanization ratio in the U.S. in 100 years, and in 50 years in England as a result of industrialization in the $19^{\text {th }}$ century (Weber 1898).

Table 3. City Groups in Turkey between 1945-1975

\begin{tabular}{|c|c|c|c|c|c|c|}
\hline & \multicolumn{3}{|c|}{1945} & \multicolumn{3}{c|}{1975} \\
\hline City Groups & $\begin{array}{c}\text { Number } \\
\text { of Cities }\end{array}$ & $\begin{array}{c}\text { Urban } \\
\text { Populatio } \\
n\end{array}$ & $\begin{array}{c}\text { Urban/ } \\
\text { Total } \\
\text { Populatio } \\
n\end{array}$ & $\begin{array}{c}\text { Numbe } \\
\text { rof } \\
\text { Cities }\end{array}$ & $\begin{array}{c}\text { Urban } \\
\text { Populatio } \\
n\end{array}$ & $\begin{array}{c}\text { Urban/Tota } \\
\text { l } \\
\text { Population }\end{array}$ \\
\hline $\begin{array}{c}10.000- \\
50.000\end{array}$ & 91 & $1,693,000$ & 0.487 & 269 & $5,544,000$ & 0.332 \\
\hline $\begin{array}{c}50.000- \\
100.000\end{array}$ & 6 & 396 & 0.114 & 29 & $1,897,000$ & 0.114 \\
\hline $100.000+$ & 4 & $1,386,000$ & 0.399 & 27 & $9,264,000$ & 0.554 \\
\hline Total & 101 & & & 325 & $\begin{array}{c}16,705,00 \\
0\end{array}$ & \\
\hline
\end{tabular}

Source: TUIK 1945, TUIK 1975. 
In 2000, rapid urbanization has continued and there were 4 cities between 1,000,000-5,000,000, 7 cities between 500,000-1,000,000; 43 cities between 100,000-500,000; 68 cities between 50,000-100,000 and 335 cities between 10,000-50,000. Meanwhile, the population of Istanbul reached to $10,018,735$. So, the hierarchy of cities has expended vertically and horizontally (See Table 4).

In 2012, there were 8 cities between 1,000,000-5,000,000, 7 cities between 500,000-1,000,000, 65 cities between 100,000-500.000, 107 cities between 50,000-100,000 and 261 cities between 10,000-50,000 together with Istanbul at the top of the hierarchy with 13,624,240 people (See Table 4). Thus, the number of cities was increased in each level of the urban hierarchy except the smallest city group due to decrease of the agricultural sector at the expense of the service and industrial sectors.

Table 4. City Groups in Turkey between 2000-2012

\begin{tabular}{|c|c|c|c|c|c|c|c|c|}
\hline $\begin{array}{c}\text { City } \\
\text { Groups }\end{array}$ & $\begin{array}{c}\text { Numbe } \\
\text { r of } \\
\text { Cities }\end{array}$ & $\begin{array}{c}\text { Urban } \\
\text { Population }\end{array}$ & $\begin{array}{c}\text { Urban/ } \\
\text { Total } \\
\text { Popula } \\
\text { tion }\end{array}$ & $\begin{array}{c}\text { Number of } \\
\text { Cities/Tota } \\
\text { I Number }\end{array}$ & $\begin{array}{c}\text { Number } \\
\text { of Cities }\end{array}$ & $\begin{array}{c}\text { Urban/ } \\
\text { Urban } \\
\text { Population } \\
\text { Populat } \\
\text { ion }\end{array}$ & $\begin{array}{c}\text { Number of } \\
\text { Cities/ } \\
\text { Total } \\
\text { Number }\end{array}$ \\
\hline $\begin{array}{c}10.000- \\
50.000\end{array}$ & 335 & $7,289,292$ & 17.46 & 73.14 & 261 & $5,612,550$ & 9.79 & 62.29 \\
\hline $\begin{array}{c}50.000- \\
100.000\end{array}$ & 68 & $4,704,588$ & 11.27 & 14.85 & 107 & $5,593,528$ & 9.75 & 15.51 \\
\hline $\begin{array}{c}100.000- \\
500.000\end{array}$ & 43 & $8,313,138$ & 19.92 & 9.39 & 65 & $12,263,370$ & 21.39 & 15.51 \\
\hline $\begin{array}{c}500.000- \\
1.000 .000\end{array}$ & 7 & $4,500,521$ & 10.78 & 1.53 & 7 & $4,857,410$ & 8.47 & 1.67 \\
\hline $\begin{array}{c}1.000 .000 \\
+\end{array}$ & 5 & $16,935,249$ & 40.57 & 1.09 & 9 & $29,015,054$ & 50.6 & 2.15 \\
\hline
\end{tabular}

Source: TUIK 2000, TUIK 2012.

Despite this rapid urbanization at the country level, it is observed that large cities are not equally distributed among the regions. In 1955, in the Marmara Region, Istanbul was the only city above 500,000 in the country. In 1975, while there were 3 cities above 500,000 in the Marmara, Aegean and Central Anatolian regions, there were none in the East and South- East Anatolia and Mediterranean and Black Sea Regions. In 1990, while there were 2 cities in the Marmara Region, 2 cities in the Central Anatolia and only one in the Aegean and the Mediterranean regions above 500,000, there were none in the East and South-east Anatolia, and the Black Sea Regions. In 2012, while the number of cities above 500,000 reached to 3 in the Marmara , South-East Anatolia and Mediterranean Regions, to 4 in the Central Anatolia Region, to 2 in the Aegean Region, 1 in the Black Sea Region and none in the East Anatolia Region. Not only mal distribution of income but also lack of large cities encourages migration from the East to the West due to insufficient job opportunities (Yazgi et al. 2014). The detection of spatial clusters of high and low per capita GDP throughout the country is an indication of the persistence of spatial disparities among the regions, (Eraydin and Armatli-Koroglu 2005) which is the main cause of mobility for the East to the West. As a result of this mobility, while some of the provinces age pyramids widened to a great extent, such as Istanbul, 
Izmir, Bursa, Kocaeli and Adana, some others became very narrow due to lass of young population, such as Uşak, Çankırı, Kırşehir (See Figure 1). It is claimed that these provinces take place between the development clusters and prevent the continuation of economic development corridors since the young and potentially better qualified members of the labor force are drawn away, the work force left behind tends to be relatively older, less educated and less adaptable to new technologies and productive methods (Simmons 1976).

Figure 1. Age Pyramids in the Provinces of Turkey in 2014

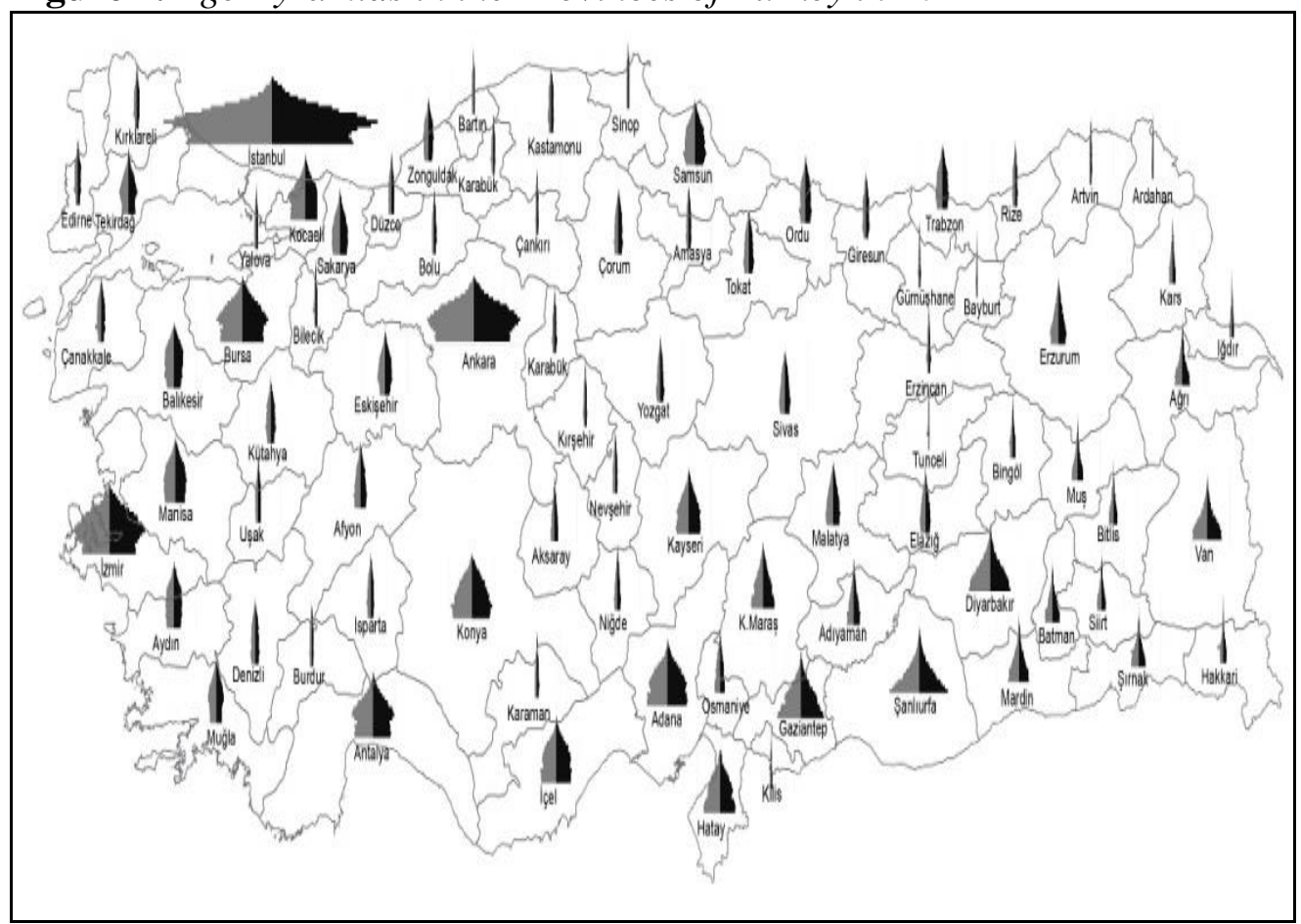

Source: Kaya and Dokmeci 2015.

In Turkey, the studies about the economic development areas are concentrated in two groups: one corridor development, the second cluster development. First, in the late 1950s, corridor development started from Kocaeli with suggestion of Rodwin (1970) to the government. Since it was accessible by sea, excellently served by rail and road transportation and located next to Istanbul which was a large market, it seemed the most advantageous location for industrial and commercial development. Later, this development has continued through time and reached Ankara at the end of the century (See Figure 2). Local realities are shaped in relation to other places; benefits may be derived from corridor development by consolidating and diversifying existing relationships with other localities (Gezer and Celebioglu 2015).

With respect to cluster analysis, Akgungor et al. (2003) identified six distinct industry clusters. Firms within the identified clusters interact with each other either formally or informally and provide potential to share technical information and knowledge transfer. Inter-cluster networking 
provides an environment for the firms to exchange information and to facilitate the diffusion of technology. The paper by Eraydin and ArmutluKoroglu (2005) presents the networking capabilities of the three important clusters of Turkey (Bursa, Denizli, Ankara) based on data collected from the sample firms in each of the industrial clusters through in-depth interviews. According to van Oort (2004), both approaches contribute to understanding the new growth theory which is based on the outcome of the dynamic and cumulative advantages of spatial productivity as already illustrated by Van Soest et al. (Van Soest et al 2006).

Figure 2. Development Levels of Provinces

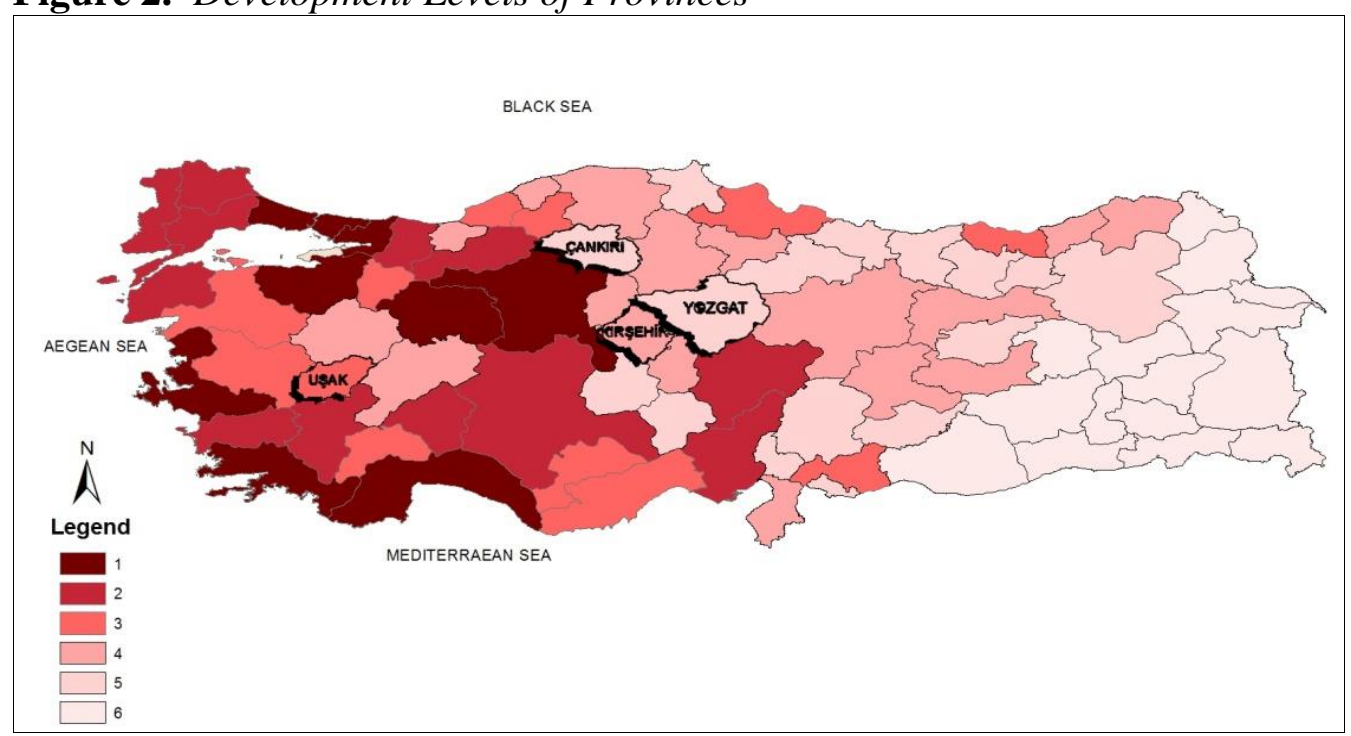

Source: SEGE 2011, Map created by author.

It is illustrated in Figure 2 that the economic interaction between the development clusters are interupted by the less developed provinces. Lack of young people in the less developed provinces discourages investors by worrying not to find workers. These disadvantaged provinces exist not only in the east but also in the West among the well- developed clusters, such as Uşak. Sometimes, these less developed provinces such as Kirsehir and Yozgat interrupt the economic interaction between the development clusters such as Ankara-Konya and Kayseri. So, investments in these provinces are crucial not only for themselves but also to increase the economic interaction among the clusters to multiply their economic impact to each other (Akgungor et al. 2010, Eraydin and Armutlu-Koroglu 2005).

\section{Locational and Demographic Analysis of Inter-provincial Migration and its Impact on the Development Corridors}

Inter-provincial migration depends on the socio-economic and demographic characteristics of the regions and on their spatial location (Yazgi et al. 2014). At the same time, the impact on the development clusters within and the outside the regions vary according to these 
characteristics. Richer regions are close to richer ones, and poorer regions to poorer ones, a non-surprising result considering the long history of regional inequalities in Turkey (Celbis and Crombrugghe 2014). The review of the development corridors and the development clusters illustrate that despite the continuous development of the Kocaeli-Ankara corridors penetration of this development into the Black Sea Region is interrupted by Cankiri which is less developed and suffered by heavy out-migration (Figure 2).

In Çankırı, out-migration is always higher than in-migration according to changing distances except the $200-400 \mathrm{~km}$. distance due to return migration, due to the lack of necessary investment in this province (Figure $3)$. With respect to the age profile, the highest pick is at the college entrance age, and the profession starting age is the second (Figure 4). Out-migration is higher than in-migration. In all age groups they are parallel to each other. Its age pyramid is very narrow and it became narrower through time (Figures 5a-5b) and it is a disadvantage for future investments. Thus, socioeconomic investments in Cankiri may serve to link the interrupted area to strengthen economic exchange on the development corridor between the Ankara's economic cluster and Samsun's economic cluster in the Black Sea Region.

Figure 3. In- and Out- Migration according Distances for Cankiri 20072008

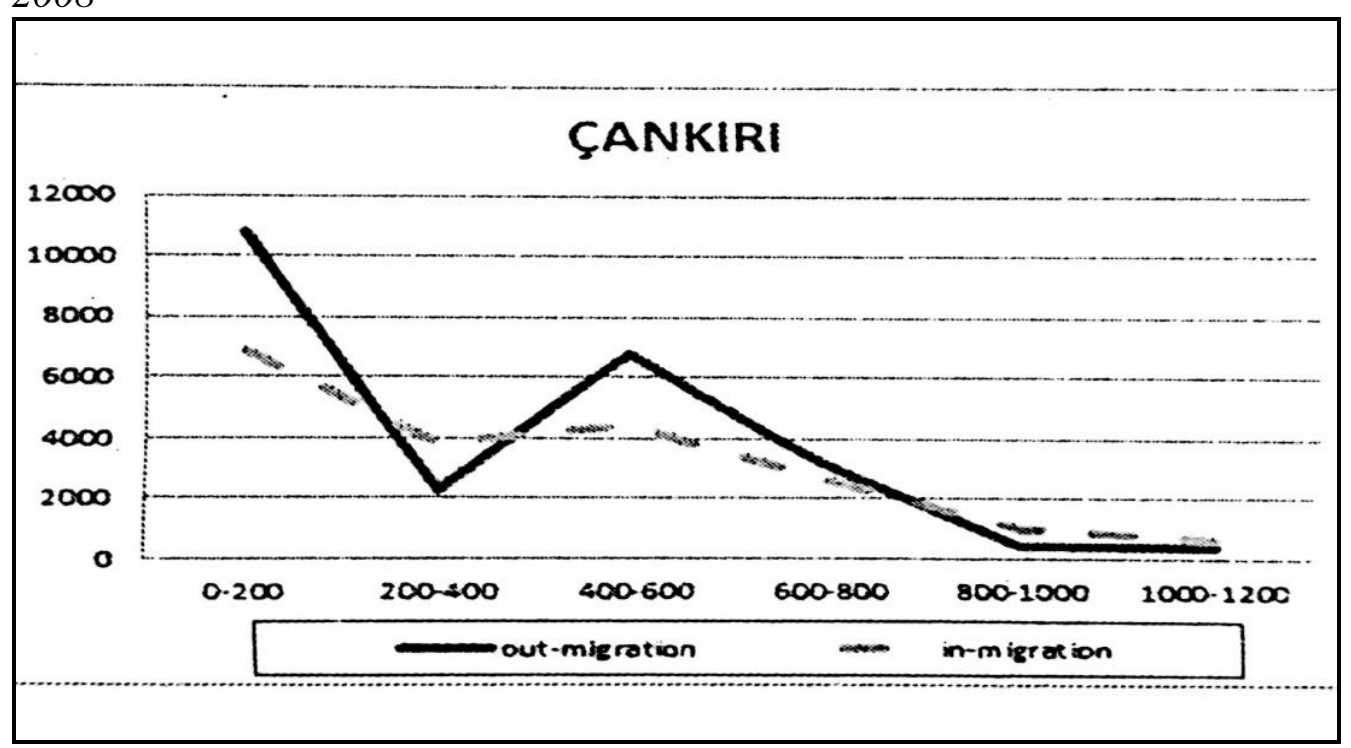

Source: Koramaz and Dokmeci 2016. 
Figure 4. In- and Out Migration according to Age Profile for Cankiri in 2007-2008

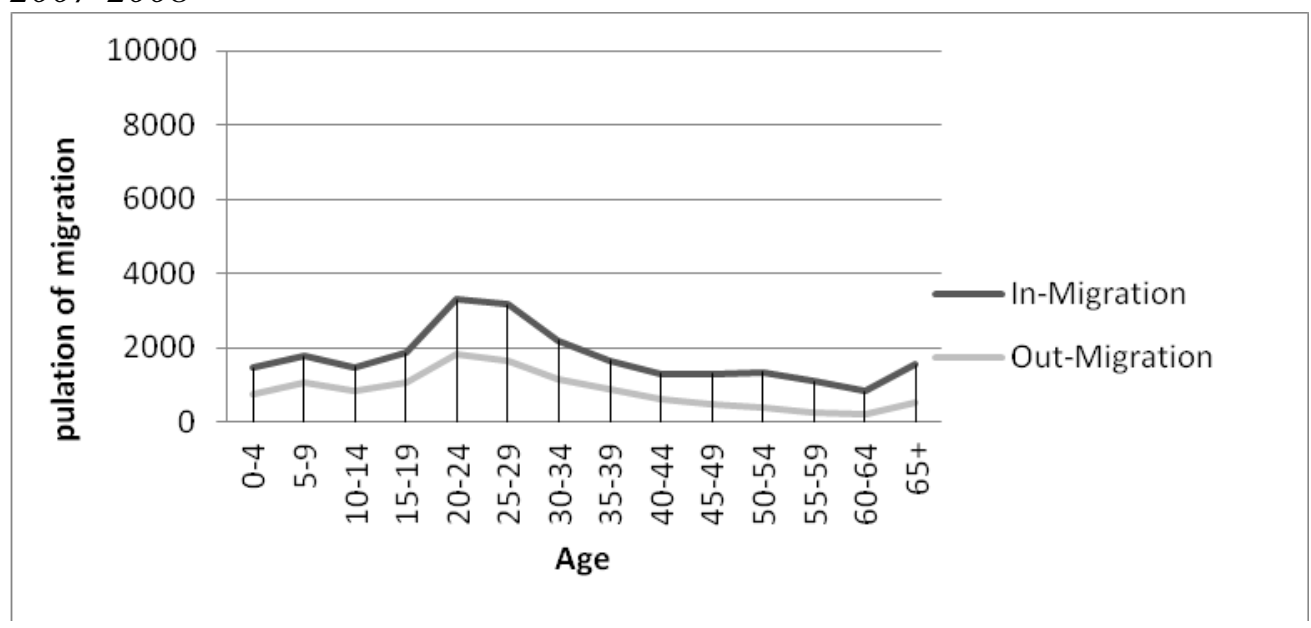

Source: Ozdemir and Dokmeci 2015.

Figure 5a. Age Pyramid for Cankiri in 2007

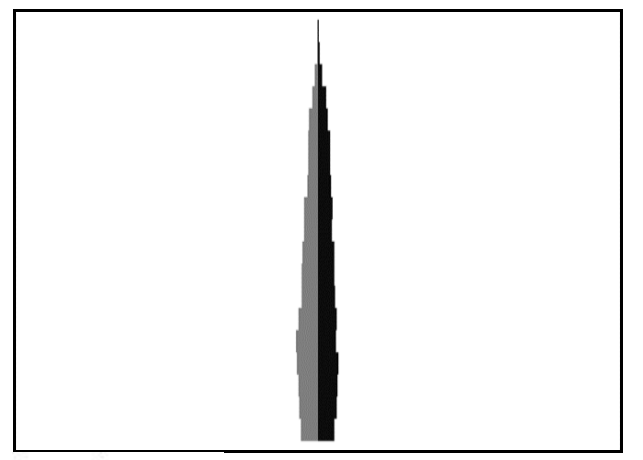

\begin{tabular}{l}
\hline Man \\
Woman
\end{tabular}
Figure 5b. Age Pyramid for Cankiri in 2014

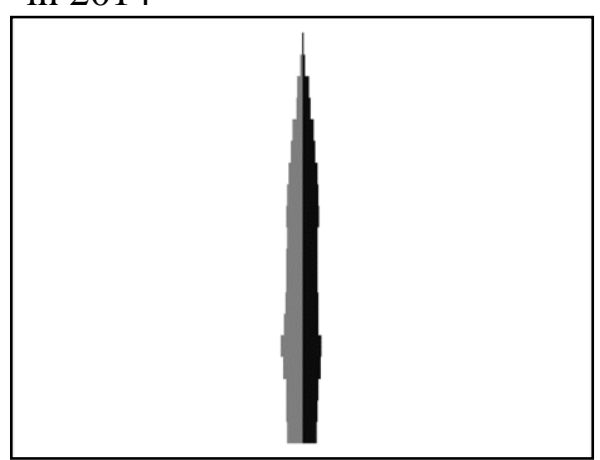

Source: Kaya and Dokmeci 2015.

Similarly in Uşak, out-migration is always higher than in-migration due to attraction of large cities for all distances in the country (Figure 6). With respect to age groups, there is more out-migration than in-migration for almost all age groups and its flatter age profile of migration is with a small peak at the college age due to lack of higher education facilities (Figure 7). Thus, its age pyramid is very narrow (Figure 8a-b) and this is considered a handicap for future investments. So, it is important to increase necessary socio-economic investment in this province in order to stimulate economic interaction with the Aegean and the Central Anatolia development clusters. 
Figure 6. In-and Out-migration in Uşak According to Distance

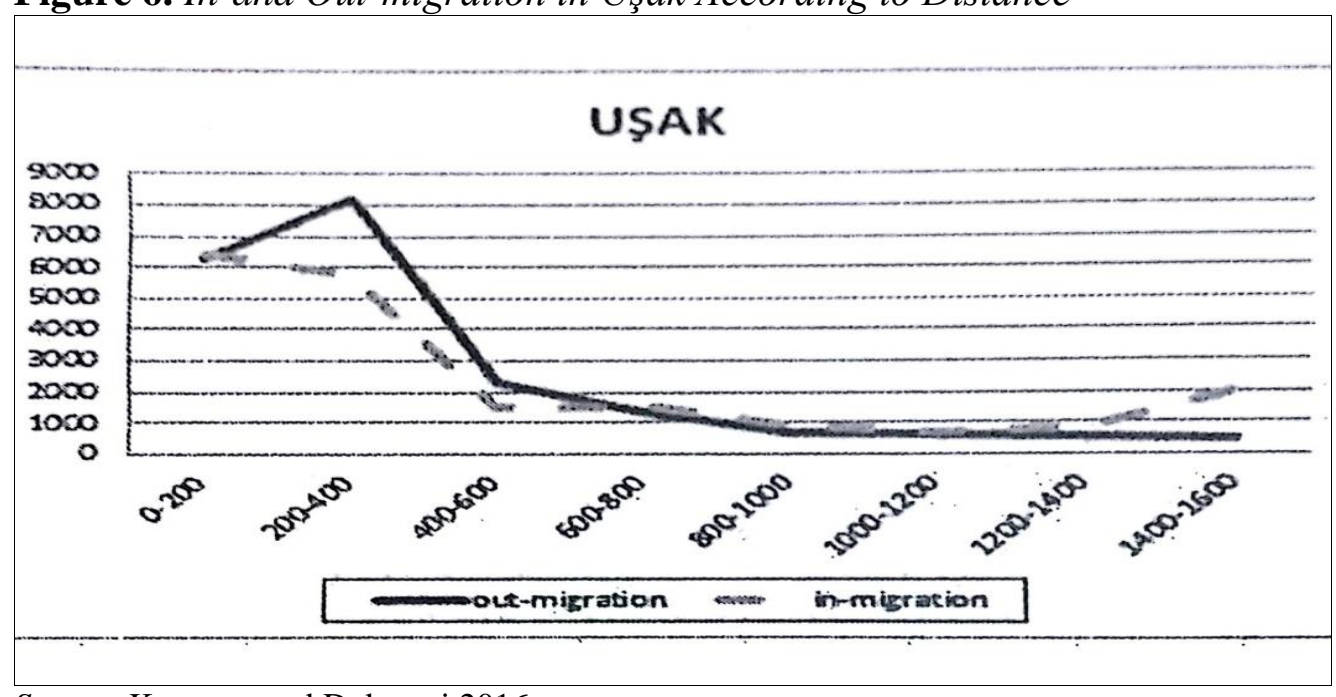

Source: Koramaz and Dokmeci 2016.

Figure 7. In-and Out-migration According to Ages in 2007-2008

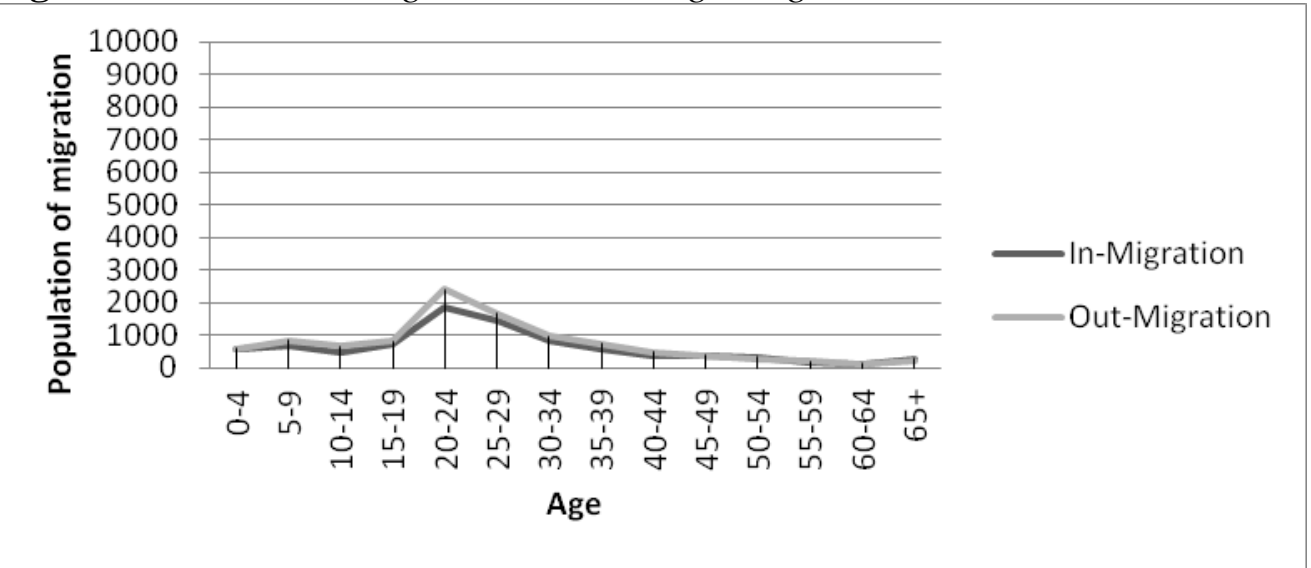

Source: Ozdemir and Dokmeci 2015.

Similarly, Yozgat is another less developed province due to its high amount of out-migration. It takes place at the beginning of the AnkaraErzurum development corridor and it interrupts the continuity of the corridor. Its' out-migration is always above the in-migration for all distances with the highest peak for Ankara and the second peak for Istanbul (Figure 9). Out-migration is above in-migration for all age groups with a small peak for the college entrance age (Figure 10). Yozgat has a very narrow age pyramid (Figure 11a-b) which is a handicap to attract investments. So, under-development is continuing as a vicious-cycle in this area. Thus, it is necessary to encourage socio-economic investment not only for the development of the province itself but also to provide continuity between theAnkara and Erzurum development corridor. 
Figure 8a. Age Pyramid in Uşak in 2007 Figure 8b. Age Pyramid in Usak in 2014
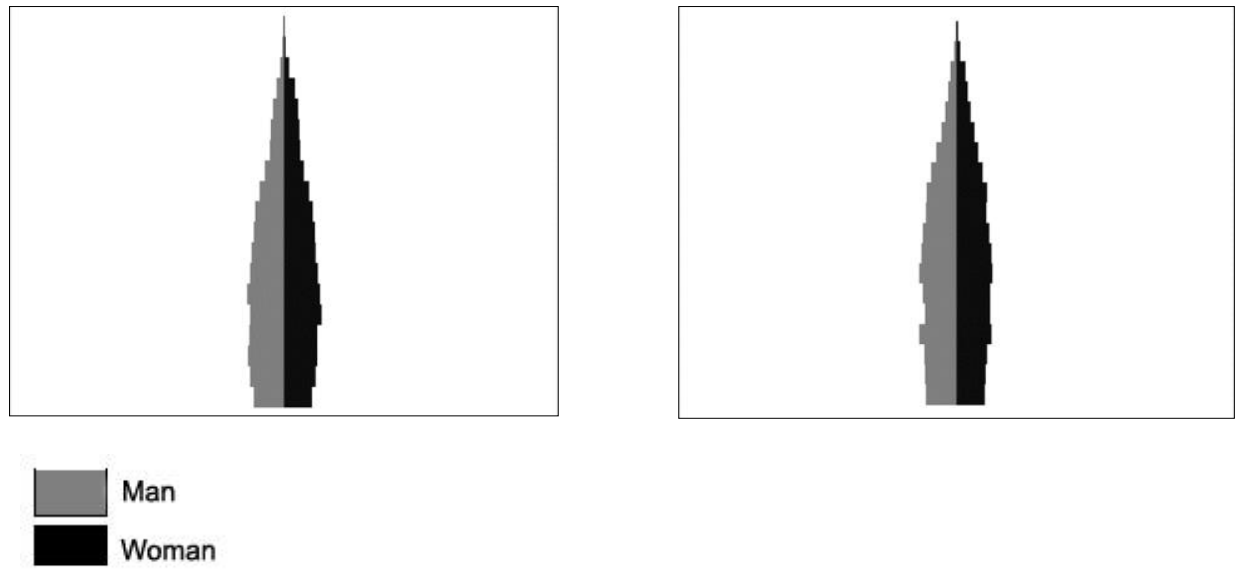

Source: Kaya and Dokmeci 2015.

Figure 9. In- and Out-Migration in Yozgat according to Distances between 2007-2008

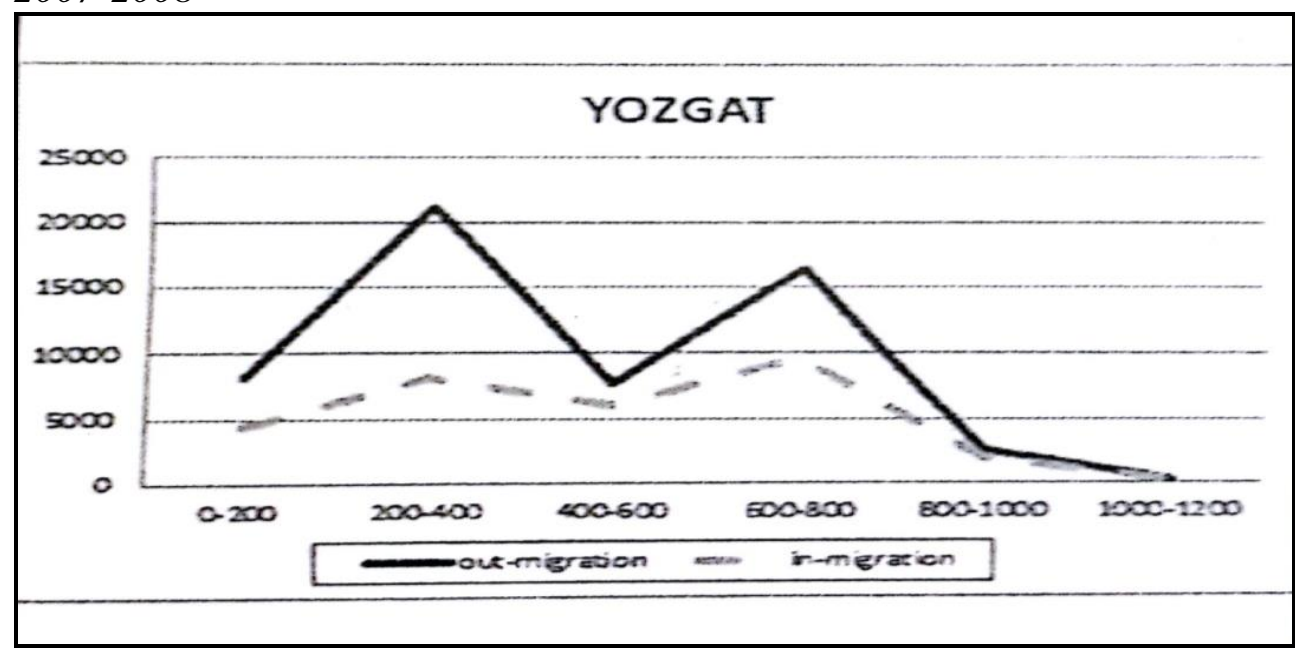

Source: Koramaz and Dokmeci 2016. 
Figure 10. Age Profiles of In- and Out-Migration in Yozgat 2007-2008

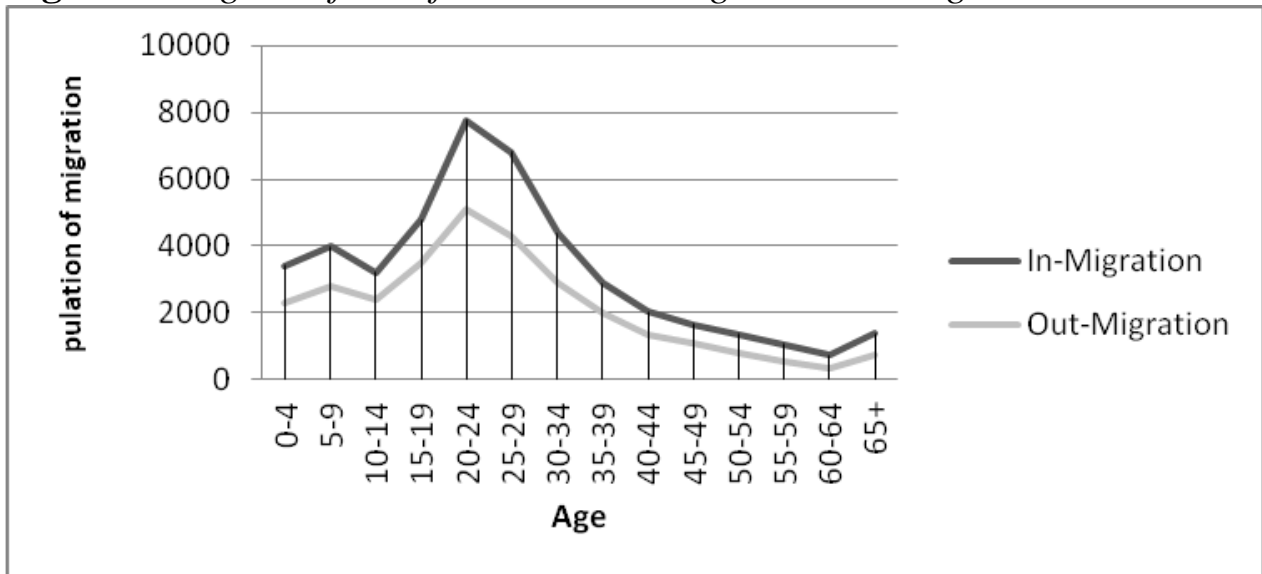

Source: Ozdemir and Dokmeci 2015.

Figure 11a. Age Pyramid in Yozgat Figure 11b. Age pyramid in Yozgat in 2007

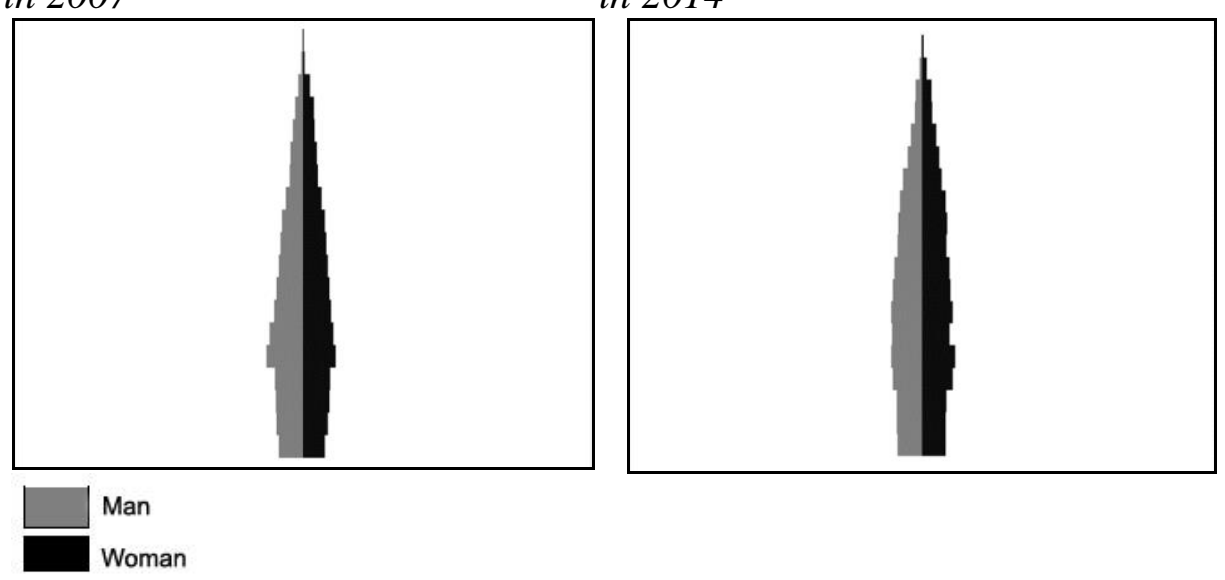

Source: Kaya and Dokmeci 2015.

In Central Anatolia, Kirsehir is another less developed province due to its high out-migration rate, which interrupts the development corridor between Ankara and Kayseri. Kursehirs' out-migration is above in-migration for all distances with the highest peak for Ankara and the second peak for Istanbul (Figure 12). The age profile of out-migration is above in-migration for all age groups with the highest peak for the college age group due to lack of educational facilities with respect to Ankara and Istanbul (Figure 13). As a result, Kirsehir has a very narrow age pyramid for the years 2007 (Figure 14a) and it has even continued to be narrower in 2014 (Figue 14b) which is a handicap to attract investments. So, to encourage socio-economic investment is not only crucial for the development of this province but also to provide the continuity of the development corridor between Ankara and Kayseri development clusters 
Figure 12. In-and Out-migration in Kırşehir According to Distances

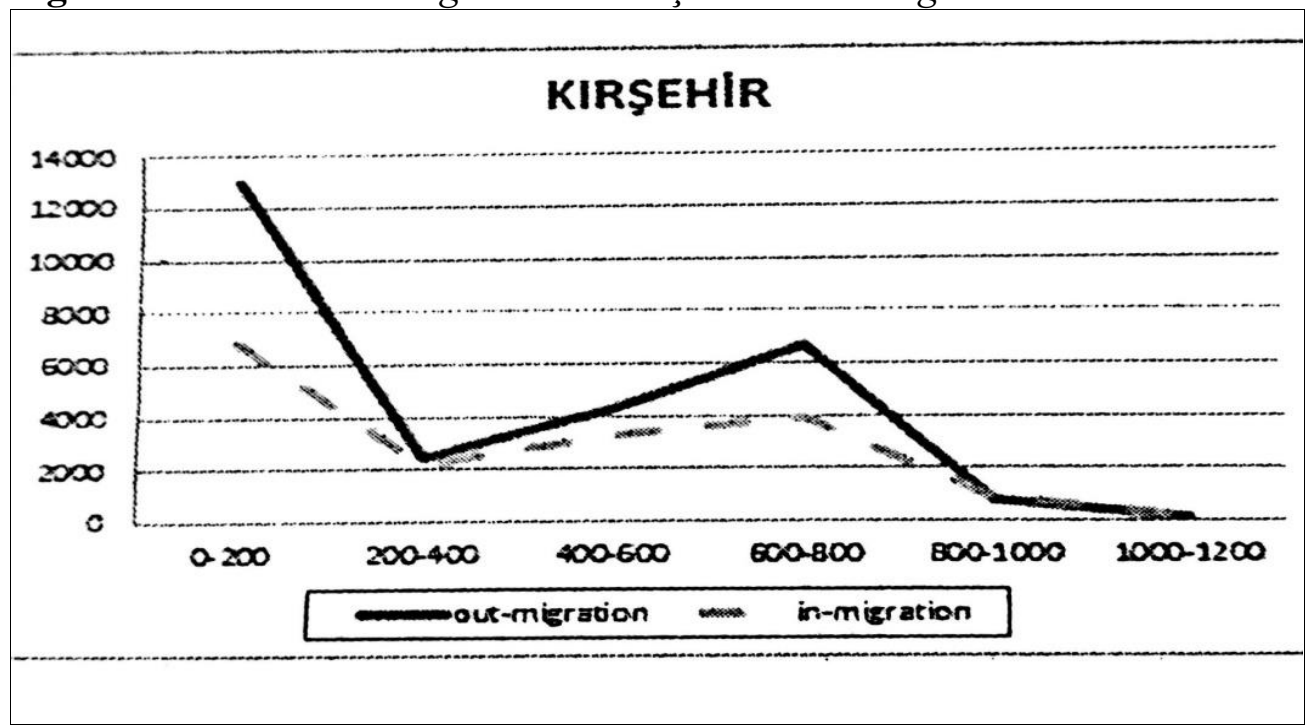

Source: Koramaz and Dokmeci 2016.

Figure 13. Age Profiles of In-and Out-Migration in Kirşehir in 2007-2008

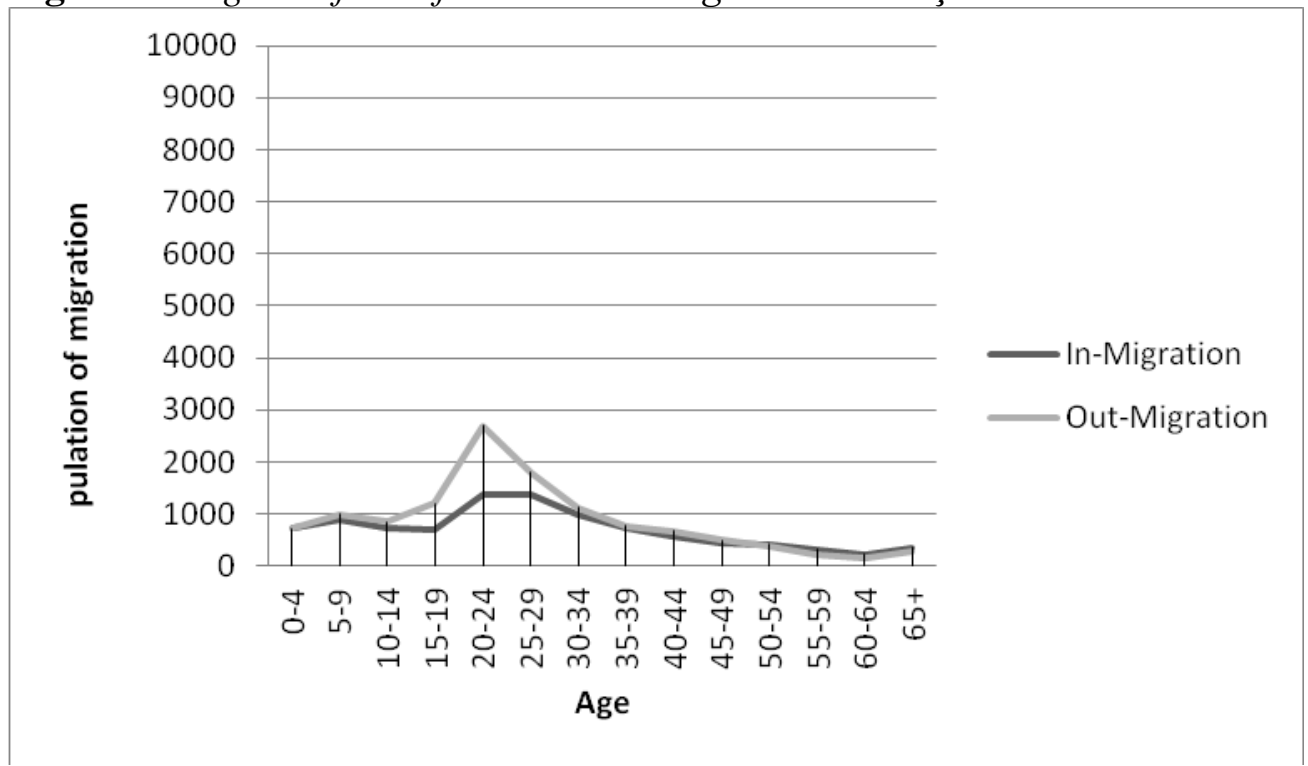

Source: Ozdemir and Dokmeci 2015. 
Figure 14a. Age Pyramid for Kırşehir in 2007
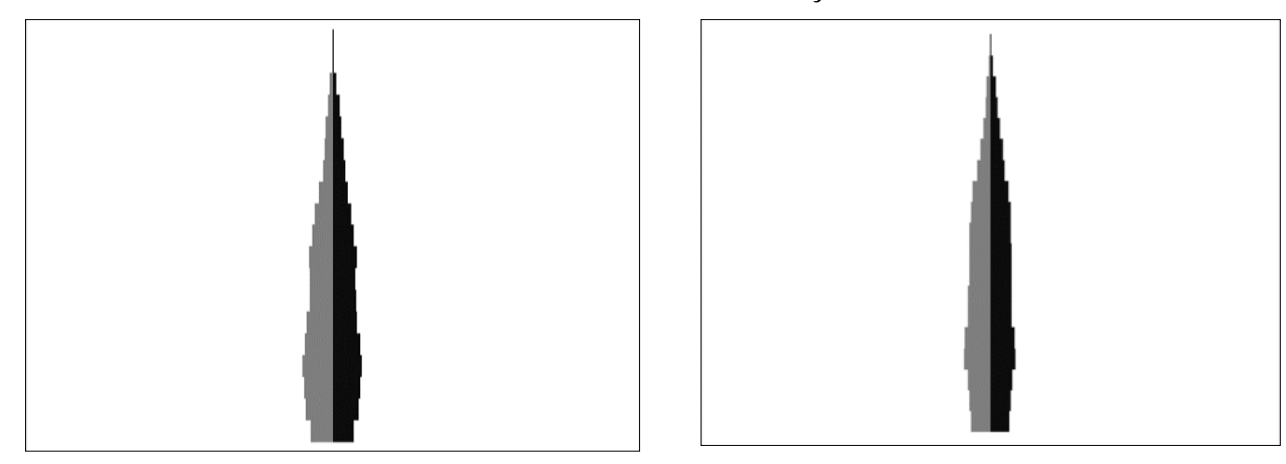

Figure 14b. Age Pyramid for in Kırşehir in 2014

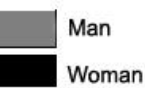

Source: Kaya and Dokmeci 2015.

Thus, development clusters in Ankara and in Konya are surrounded by the less developed provinces which do not allow to originate development corridors from them in the central Anatolia. Therefore, it is very crucial socioeconomic development of these provinces for the better integration of the country in economic terms.

\section{Conclusion}

This study illustrated the impact of in-and out-migration on the demography of the provinces in the economically strategic locations under the influence of large metropolitan areas in Turkey. Large cities were always attractive to migrants with their abundant service and industrial jobs and higher quality education and health facilities. Especially, at the beginning of $21^{\text {th }}$ century, the closing down of government factories as a result of privatization and the implementation of a free trade policy at the country level, as well as government supply of large construction projects, and investments from national and international manufacturing companies increased the attractiveness of the large cities to migrants. In other words, in-migration is caused as a result of the influx of manufacturing and service jobs from the developed economies and workers displaced by agricultural and technological adjustments. This study sought to improve the understanding of contemporary population redistribution trends by examining age pyramids of provinces with respect to age profiles of in-and out-migration, and according to the distances to major metropolitan areas within the perspective of economic systems of Turkey.

In the present study, first, the development of the urban system during the second half of the century and socio-economic differences between the East and West of the country are described. In other words, increase in the number 
of different size cities in the urban hierarchy are given through time, and income per capita, the ratio of industrial and service jobs are compared among the regions which causes continuous population mobility between the East and West. So, research on this mobility reveals that while large metropolitan areas pose key advantages for the young migrants, small towns with good amenities, mild climates and lower living costs are preferable for the old migrants. As time advances, people make adjustments in their location reflective of their changing conditions as they anticipate the next period of their lives. This situation causes depopulation of disadvantaged provinces which has unrepairable conditions for their economic development, especially in the East.

Further, the investigation of age pyramids with respect to the distance to large metropolitan areas reveals that if the conditions are convenient for the development of industry which cannot find place in the large city or desire to benefit from the market potential of the large city, the neighboring cities also become new metropoles, such as Kocaeli and Bursa. If not, the neighboring provinces cannot provide jobs and start to loose, especially young people and thus, their age pyramids narrow and turn to beanpoles, such as Çankırı which is located next to Ankara. On the other hand, the hierarchical impact of these new metropole's on their surroundings in two ways: 1 . the surrounding establishments benefit from the market potential of the new metropoles and they hold their population to some extent, such as Balikesir next to Bursa. However, they cannot compete with large metropoles with respect to higher education and top level jobs and they lose some of their young people to the large metropoles; 2 . The surrounding establishments cannot compete with new metropoles and they lose their population and their age pyramids turn to beanpoles, such as Çankırı.

Meanwhile, during the last half century, despite the intensive development of the corridor between Istanbul and Ankara, since the development clusters of Ankara and Konya are surrounded by less developed provinces under heavy out-migration, they cannot nourish the continuity of development corridors any further. Thus, due to their strategic central locations, it is very crucial to the socio-economic development of these provinces in order to encourage the development corridors in the east and west directions.

In order to realize sustainable or inclusive development, it is important that policy-makers develop a more dynamic view taking into account how development will result in a dynamic space. Progress in one place is a cause of stagnation in another and vice versa (Van Westen 2011).

The results of this study can be useful for urban and regional planners, politicians, administrators and investors. Future migration research is suggested to incorporate the economic determinants of evolving spatial patterns in a temporal perspective together with life-cycle influences on migration by taking into consideration the education level and professions of migrants. 


\section{References}

Akgungor S, Kumral N, Lenger A. (2010) National Industry Clusters and Regional Specializations in Turkey, European Planning Studies 11(6): 647-669. do1: 10.1080/0965431032000108378.

Baccaini B. (2007) Inter-regional migration flows in France over the last fifty years. Population 62(1): 139-155.

Celbis MG, Crombrugghe D (2014) Can internet infrastructure help reduce regional disparities? Evidence from Turkey. Paper presented at the UNU-MERIT Conference: Future Perspectives on Innovation and Governance in Development, (26-28 Nov.). Maastricht, the Netherlands.

Celebioglu F, Dall'erba S (2010) Spatial disparities across the regions of Turkey: An exploratory spatial data analysis. The Annals of Regional Science 45(2): 379-400.

Clark DE, Hunter WJ (1992) The impacts of economic opportunity, amenities and fiscal factors on age-specific migration rates. Journal of Regional Science 32(3): 349-365.

Clark WAV, Onaka JL (1983) Life-cycle and housing adjustment as explanation of residential mobility. Urban Studies 20(1): 47-57.

Deteng-Dessendre C, Goffette-Nagot F, Piqeut V (2008) Life-cycle and migration to urban and rural areas: Estimation of a mixed logit model on French data. Journal of Regional Science 48(4): 789-824.

Dokmeci V, Berkoz L (2000) Residential location preferences according to demographic characteristics in Istanbul. Landscape and Urban Planning 48(1-2): 45-53.

Eraydin A, Armatli-Koroglu B (2005) Innovation, networking and the new industrial clusters: the characteristics of networks and local innovation capabilities in the Turkish industrial clusters. Entrepreneurship and Regional Development 17 July: 237-266.

Evcil AN, Dokmeci V, Kiroglu G (2006) Regional migration in Turkey: Its directions and determinants. European Congress of Regional Science, Volos, Greece.

Gedik A (1997) Internal migration in Turkey, 1965-1985: Test of conflicting findings in the literature. Review of Urban and Regional Development 9(2): 170-179.

Gezer MA, Celebioglu F (2015) Manufacturing sector concentration and seeking for alternative region beside Marmara Region in Turkey: A spatial analysis. $3^{\text {rd }}$ International Conference on Urban and d Regional Economics, the Annual Meeting of ERSA-Polish Section, 11-12 June, Katovice.

Gezici F, Hewings GJD (2007) Spatial analysis of regional inequalities in Turkey. European Planning Studies 15(3): 383-403.

Gordon L, Lamont D. (1998) A model of labour-market interdependencies in the London Region. Environment and Planning A 14: 237-264.

Kaya HS, Dokmeci V (2015) The Impact of migration on the Demographic Structure of Provinces in Turkey. [ in the publication process].

Kontully T, Schon KP (1994) Changing Western Germany internal migration system during $2^{\text {nd }}$ half of the 1980s. Environment and Planning A 26(10): 1521-1543.

Koramaz K, Dokmeci V (2016) The impact of distance on the migration in Turkey. Migration Letters 13(2): 269-294.

Lee ES (1966) A Theory of Migration. Demography 3(1): 47-57.

Liang Z, Chen YP, Gu Y (2002) Rural industrialization and internal migration in China. Urban Studies 39(12): 2175-87. 
Liaw KL (1990) Joint effects of personal factors and ecological variables on the interprovincial migration pattern of young adults in Canada. Geographical Analysis 22(3): 189-208.

Ozdemir Z, Dokmeci V (2015) Demographic analysis of inter-provicial migration in Turkey. [in the publication process].

Plane DA (1993) Demographic influences on migration. Regional Studies 27(4): 375383.

Rodwin L (1970) Nations of Cities: A Comparison of Strategies for Urban Growth. Boston, Mass.: Houghton-Mifflin.

Samers M (2009) Migration. London: Rouledge.

SEGE (2011) Research on the Socio-Economic Development Ranking of Provinces and Regions. Regional Development and Structural Adjustment, Ankara

Siegel J, Woodyard M (1974) Position in the urban hierarchy as a determinant of inmigration. Land Economics 50(1): 75-81.

Simmons AB (1976) Opportunity space, migration and economic development: A critical assessment of research on migrant characteristics and their impact on rural and urban communities. In A Gilbert (Ed) Development Planning and Spatial Structure. London: John Wiley \& Sons.

Skeldon R (1990) Population Mobility in Developing Countries. London: Belhaven Press.

Tanfer K (1983) Internal migration in Turkey: Socioeconomic characteristics by destination and type of move, 1965-1970. Studies in comparative International Development 18(4): 76-111.

Tekeli I (2008) Regional Inequality in Turkey and Regional Planning Papers. Istanbul: History Foundation, Yurt Publications.

TUIK (1945) Population Census. Turkish Statistical Institute.

TUIK (1975) Population Census. Turkish Statistical Institute.

TUIK (1990) Population Census. Turkish Statistical Institute.

TUIK (2000) Population Census. Turkish Statistical Institute.

TUIK (2003) Population Census. Turkish Statistical Institute.

TUIK (2012) Address Based Population Registration System. Turkish Statistical Institute.

Tobler W (1995) Migration, Ravenstein, Tornthwaite, and beyond. Urban Geography 16(4): 327-343.

Van Oort F (2004) Urban Growth and Innovation. Ashgate: Aldershot.

Van Soest DP, Gerking S, Van Oort FG (2006) Spatial impacts of agglomeration externalities. Journal of Regional Science 46(5): 881-899.

Van Westen ACM (2011) Introduction: Translocal development, development corridors and development chains. International Development Planning Review 33(4).

Var EB, Yazg1 B, Dokmeci V (2014) Age and cohort analysis of regional migration in Turkey. Regional Science Inquiry 6(1): 81-94.

Weber A (1898) The Growth of Cities. New York: Columbia University Press.

Walters WH (1994) Climate and U.S. elderly migration rates. Papers in Regional Science 73(3): 309-329.

Walters WH (2002) Place characteristics and later life migration. Research on Aging 24(2): 243-277.

Willis K (2010) Introduction: Mobility, migration and development. International Development Planning Review 32(3-4): 1-13. 
Yazgi B, Dokmeci V, Koramaz K, Kiroğlu G (2014) Impact of characteristics of origin and destination provinces on migration: 1995-2000. European Planning Studies 229(6): 1182-1198. 